\title{
Long term follow up in type A insulin resistant syndrome treated by insulin-like growth factor I
}

\author{
Hiromi Ishihama, Yoshimi Suzuki, Kanji Muramatsu, Miseho Nagai, Minoru Kokubo, \\ Hisayuki Shiraya, Akira Kawakita, Yutaka Nishimura, Takeshi Imamura, \\ Masashi Kobayashi
}

\begin{abstract}
Insulin-like growth factor I (IGF-I) is a useful therapeutic agent in insulin resistant diabetes mellitus due to insulin receptor disease because of its hypoglycaemic effects through the IGF-I receptor. A girl with typical type A insulin resistant syndrome was treated with IGF-I for two years and the treatment was effective in ameliorating hyperglycaemia. Overproduction of testosterone in polycystic ovaries was aggravated with this treatment, however. Therefore, IGF-I treatment may be used for glycaemic control but with caution because of its possible side effect of aggravating hyperandrogenism in these patients.

(Arch Dis Child 1994; 71: 144-146)
\end{abstract}

The characteristic features of type A insulin resistant syndrome are extreme insulin resistance, acanthosis nigricans, and ovarian hyperandrogenism. The mechanism of the insulin resistance is either a defect in insulin receptor itself or postreceptor abnormality. Recently, several investigators have reported various mutations or deletions of insulin receptor gene in this disorder, ${ }^{1-3}$ which cause decreased receptor number, decreased binding affinity, or abnormality in signal transduction due to a kinase defect. On the other hand, although it has been speculated that acanthosis nigricans and ovarian hyperandrogenism originate from secondary hyperinsulinaemia, the precise mechanism is still unclear. ${ }^{4}$

Insulin-like growth factor I (IGF-I) has growth promoting activity and also metabolic effects through the IGF-I receptor. Therefore, IGF-I may be an appropriate therapeutic agent for type A insulin resistant syndrome. We treated a girl with typical type A insulin resistant syndrome with IGF-I for two years to observe whether these clinical features may be affected by the treatment.

\section{Case report}

The patient was a girl, aged 11 years, who was found to have glucosuria on a routine urine screening test. There was neither a history of parental consanguinity nor a family history of diabetes mellitus. She was $144 \mathrm{~cm}$ in height $(-0.72 \mathrm{SD})$ and her body weight was $40.5 \mathrm{~kg}$ $(-0.07 \mathrm{SD})$. She had amenorrhoea, acanthosis nigricans in her axilla, and marked hirsutism on the face and extremities. An oral glucose tolerance test revealed a diabetic pattern and hyperinsulinaemia. At 120 minutes, plasma glucose concentration was $19.0 \mathrm{mmol} / \mathrm{l}$ and plasma insulin was above $1920 \mathrm{pmol} / \mathrm{l}$. Insulin tolerance tests $(0 \cdot 1 \mathrm{U} / \mathrm{kg}$ and $0.3 \mathrm{U} / \mathrm{kg})$ showed no significant effect on the plasma glucose concentration. Exogenous insulin $(0.3 \mathrm{U} / \mathrm{kg})$ lowered the plasma glucose only to $60 \%$ of the previous value. Glycated haemoglobin $\left(\mathrm{HbA} \mathrm{l}_{\mathrm{c}}\right)$ was raised $(7 \cdot 0 \%$, normal range $3 \cdot 5-5 \cdot 5 \%)$. Ultrasonographic examination demonstrated polycystic ovaries. Neither anti-insulin nor antiinsulin receptor antibody were detectable in her serum. These findings showed that she had type A insulin resistant syndrome. She was observed without regular insulin treatment.

\section{Methods}

The method for the ${ }^{125}$ I-insulin binding to erythrocytes, transformed lymphocytes, and cultured fibroblasts has been described by Sasaoka et al. ${ }^{5}$ Surface labelling of EpsteinBarr virus transformed lymphocytes was determined by the method described previously. ${ }^{7}$ We performed subsequent DNA analysis of insulin receptor gene by a modification of the method described by Kusukawa et $a l^{8}$ and examined transfection of insulin receptor c-DNA to COS7 cells according to the method of Kobayashi et al. ${ }^{9}$

Recombinant human IGF-I was provided by the Fujisawa pharmaceutical industry (Osaka, Japan). Treatment was started at the age of 13 years after informed consent was obtained from the patient and her parents. Lyophilised IGF-I freshly dissolved in normal saline was injected subcutaneously before breakfast and supper every day. The initial dose, which was determined by the dose trial study, was 0.25 $\mathrm{mg} / \mathrm{kg} / \mathrm{dose}$. She did not receive any other medication. Blood sampling was done on admission and thereafter every three months to evaluate her plasma glucose profile, $\mathrm{HbA} 1_{c}$, fructosamine, plasma insulin, and total IGF-I. Routine haematological and biochemical examinations were also performed at the same time. Serum testosterone concentration was serially examined every four months after treatment. Height and weight were measured on each admission. A luteinising hormone releasing hormone (LH-RH) stimulation test was carried out at pretreatment and 19 months after the treatment.

\section{Results}

Insulin binding to erythrocytes, transformed lymphocytes, and cultured fibroblasts was 


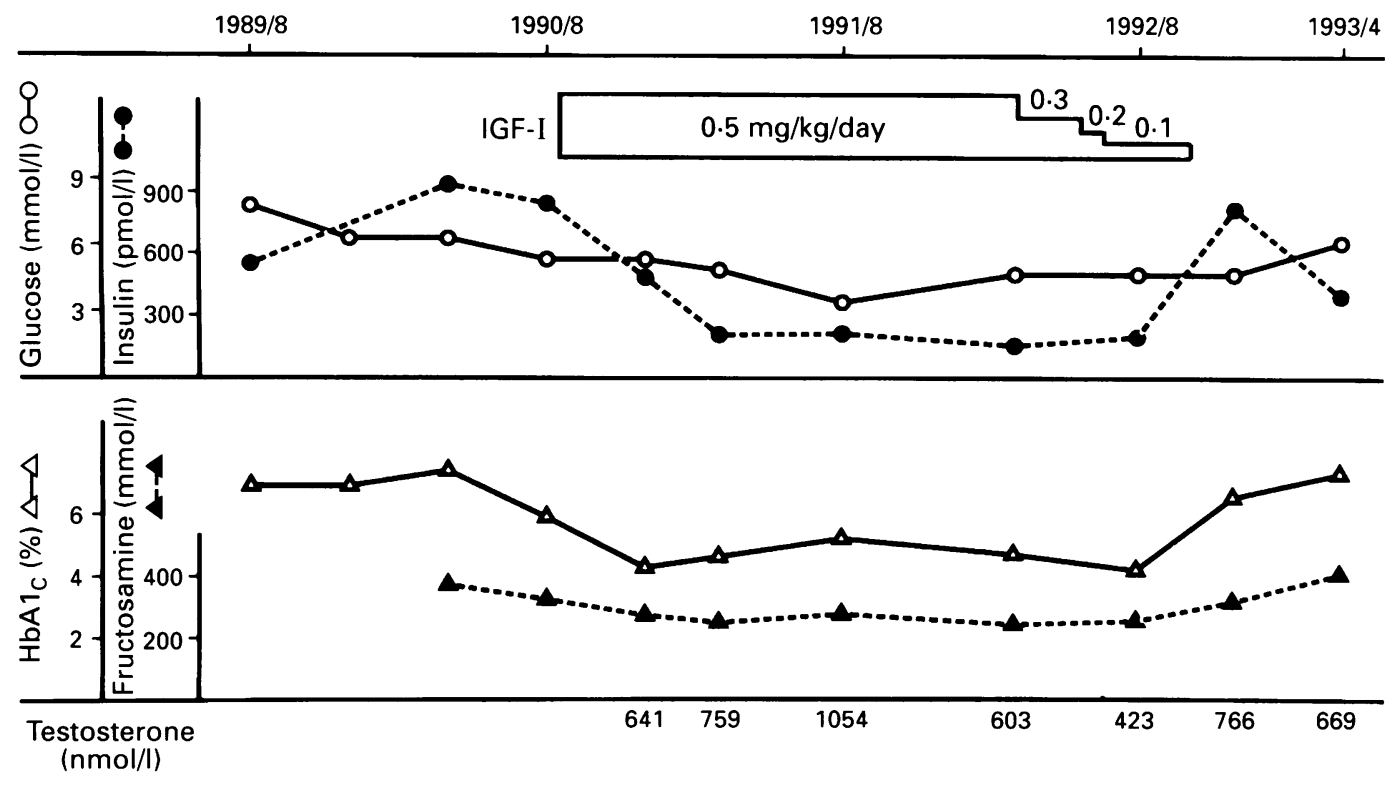

Clinical course showing concentrations of fasting plasma glucose and insulin, $H b A 1_{\mathrm{c}}$, and fructosamine. (Dates are shown year/month.)

decreased to $14-35 \%$ of normal. A surface labelling study in transformed lymphocytes demonstrated a decreased number in insulin receptors. Subsequent DNA analysis of insulin receptor gene revealed a heterozygous point mutation substituting codon TGG for TTG in exon 20 which changed $\operatorname{Trp}^{1193}$ of insulin receptor to Leu. Furthermore, insulin binding to the COS7 cell transfected with the mutant c-DNA was decreased to $28 \%$ of normal.

After the administration of IGF-I, plasma glucose, plasma insulin, $\mathrm{HbAl}_{c}$, and fructosamine concentrations became normalised as shown in the figure. Serum concentrations of IGF-I were raised from $15-33 \mathrm{nmol} / 1$ to 60-116 nmol/l. During the treatment, the patient did not have any hypoglycaemic attacks or abnormal routine laboratory data. Acanthosis nigricans also seemed to improve gradually. On the contrary, hirsutism, particularly her moustache and beard hair, became worse and her serum testosterone concentration slowly increased, although there was no significant change in the LH-RH stimulation test at pretreatment and 19 months after the treatment. Polycystic ovaries were unchanged on ultrasonographic approach throughout the clinical course. Interestingly, the testosterone concentration decreased in parallel with reducing the dose of IGF-I to avoid the possible influence of IGF-I on testosterone production and hirsutism. IGF-I treatment was finally stopped at the patient's and parents' request. Consequently, her plasma glucose, plasma insulin, $\mathrm{HbAl}_{\mathrm{c}}$, and fructosamine concentrations increased and serum testosterone also returned to raised values. Height gain was not achieved by the treatment probably due to her advanced bone age which was already 14.8 years old at the time of the start of the treatment.

\section{Discussion}

Type A insulin resistant syndrome has been proved to be due to abnormalities of insulin receptor molecule by recent gene technology. Some patients with this disease may require massive doses of exogenous insulin for diabetic control, but most do not adequately respond to insulin treatment. ${ }^{10}$ From this viewpoint, we treated such a patient with IGF-I and found that the long term IGF-I administration was very effective for glycaemic control in type A insulin resistant syndrome.

There was another reason for selecting IGF-I as the choice for treatment of extreme insulin resistant syndrome with mild diabetes mellitus such as in our case. Namely, we expected IGF-I might improve acanthosis nigricans and ovarian hyperandrogenism by decreasing plasma insulin concentrations as it has been suggested that these features are due to hyperinsulinaemia. ${ }^{11}$ However, serum testosterone was increased by the treatment. Furthermore, it decreased in proportion to the reduced dose of IGF-I and again increased moderately as hyperinsulinaemia returned with the interruption of IGF-I treatment. These findings not only suggested that IGF-I administration could aggravate overproduction of testosterone in type $\mathrm{A}$ insulin receptor disease, but also supported animal experimental data that showed that IGF-I as well as insulin was capable of augmenting androgen synthesis in ovarian theca interstitial cells. ${ }^{12-14}$ In our patient, IGF-I treatment seemed to cause a different therapeutic effect on acanthosis nigricans and hyperandrogenism. However, it was not certain whether IGF-I was directly related to these manifestations as there was no significant change in clinical features at six months after the end of the treatment.

In conclusion, IGF-I administration is effective in ameliorating hyperglycaemia in cases of type A insulin resistant syndrome, but it is important to be aware that IGF-I may aggravate hyperandrogenism in these patients.

We are grateful to Dr Fumihiko Mizutani and Dr Haruyo Inagaki (Nagoya City University, Aichi, Japan) for their clinical support. 
1 Kobayashi M, Sasaoka T, Shigeta Y, et al. Insulin resistance by unprocessed insulin proreceptors: point mutation at 657-63.

2 Odawara M, Kadowaki T, Taylor SI, et al. Human diabetes associated with a mutation in the tyrosine kinase domain
of the insulin receptor. Science 1989; 245: 66-8.

3 Taira M, Hashimoto N, Yoshida S, et al. Human diabetes associated with a deletion of the tyrosine kinase domain of the insulin receptor. Science 1989; 245: 63-6.

4 Moller DE, Flier JS. Insulin resistance - mechanisms, syndromes, and implications. $N$ Engl f Med 1991; 325: 938-48.

5 Sasaoka T, Shigeta Y, Kobayashi M, et al. Binding specificity and intramolecular signal transmission of uncleaved insulin proreceptor in transformed lymphocytes from a patient with extreme insulin resistance. Diabetologia 1989; 32: 371-7.

6 Sasaoka T, Kobayashi M, Hisatomi A, et al. Clarification of signaling pathways mediated by insulin and insulin-like growth factor I receptors in fibroblasts from patients with specific defect in insulin receptor. Diabetes 1988; 37: 1515-23.

7 Kobayashi M, Sasaoka T, Shigeta Y, et al. Insulin resistance by uncleaved insulin proreceptor: emergence of binding site by trypsin. Diabetes $1988 ; 37$ : 653-6.
8 Kusukawa N, Uemori T, Kato I, et al. Rapid and reliable protocol for direct sequencing of material amplified by the polymerase chain reaction. Biotechniques 1990; 9: 66-72. Kobayashi M, Sugibayashi M, Shigeta Y, et al. Transfection of $\mathrm{cDNA}$ with $\mathrm{G} \rightarrow \mathrm{T}$ point mutation at the cleavage site of insulin receptors to COS7 cells. Biochem Biophys Res

10 Quin JD, Fisher BM, Paterson KR. Acute response to recombinant insulin-like growth factor $I$ in a patient with Mendenhall's syndrome. N Engl $\Im$ Med 1990; 323: 1425-6.

11 Taylor SI, Dons RF, Gorden P, et al. Insulin resistance associated with androgen excess in women with autoantibodies to the insulin receptor. Ann Intern Med 1982; 97: 851-5.

12 Hernandez ER, Resnick CE, Adashi EY, et al. Somatomedin-C/insulin-like growth factor I as an enhancer of androgen biosynthesis by cult cells. Endocrinology 1988; 122: 1603-12.

13 Cara JF, Rosenfield RI Insulin-like growth factor I and insulin potentiate luteinizing hormone-induced androgen synthesis by rat ovarian thecal-interstitial cells. Endocrinology 1988; 123: 733-9.

14 Magoffin DA, Kurtz KM, Erickson GF. Insulin-like growth factor I selectively stimulates cholesterol side-chain cleavage expression in ovarian theca-interstitial cells. Mol Endocrinol 1990; 4: 489-96. 